\title{
Penatalaksanaan kandidiasis oral disebabkan Candida tropicalis pada anak dengan gangguan sistemik
}

\author{
*Cane Lukisari, **Dwi Setyaningtyas, **Mintarsih Djamhari \\ "PPDGS Ilmu Penyakit Mulut Fakultas Kedokteran Gigi Universitas Airlangga \\ **Bagian Penyakit Mulut, Rumah Sakit Angkatan Laut dr. Ramelan \\ *** Departemen Ilmu Penyakit Mulut Fakultas Kedokteran Gigi Universitas Airlangga \\ Surabaya, Indonesia
}

\begin{abstract}
Oral candidiasis is an oral mucosal infection caused by Candida albicans (CA) or non-Candida albicans Candida (NCAC). C. tropicalis (CT) is most virulent NCAC because it has the most adherence ability to epithelial cells in vitro as well as medium level proteinase secretion. In addition, CT is the second most common colony found in human. Although incidence rate of oral infection was low, this species has virulence potency, lately reported as the mayor cause of candidemia in immunocompromised patients. This paper reports and discusses oral candidiasis due to CT in a child who suffered anemia with clinical sign of malnutrition. Oral nystatin suspension is therapy of choice because of patient well response, and in vitro studies reported lack of response of fluconazole to candidemia due to C.tropicalis. However, nystatin oral suspension, should be synchronized with hygiene optimalization of elimination of predisposition factors, and supportive therapy would provide a good prognosis.
\end{abstract}

Key words: oral candidiasis, Candida tropicalis, anemia

\begin{abstract}
ABSTRAK
Kandidiasis oral adalah kelainan pada mukosa rongga mulut yang disebabkan oleh $C$. albicans (CA) maupun non-Candida albicans Candida (NCAC). C.tropicalis (CT) merupakan salah satu spesies NCAC yang mempunyai virulensi paling tinggi karena tingginya kemampuan perlekatan pada sel-sel epitel dan mensekresi proteinase dalam level sedang. CT juga merupakan spesies Candida kedua yang paling sering dijumpai pada manusia. Walaupun angka insidensi infeksi dalam rongga mulut kecil tetapi spesies ini mempunyai potensi virulensi menjadi penyebab kandidemia oleh karena NCAC pada pasien imunokompromis. Laporan kasus ini membahas tentang kandidiasis oral yang disebabkan CT pada anak penderita anemia dengan tanda klinis malnutrisi. Nystatin suspensi oral dipilih sebagai terapi pilihan, mengingat beberapa penelitian sebelumnya melaporkan bahwa terapi kandidemia karena CT dengan fluconazol in vitro menunjukkan respon yang kurang menggembirakan. Pada kasus ini sediaan nystatin suspensi oral disertai optimalisasi oral hygiene, eliminasi faktorfaktor predisposisi serta terapi suportif memberikan prognosis yang baik.
\end{abstract}

Kata kunci: kandidiasis oral, Candida tropicalis, anemia

Koresponden: Cane Lukisari, Peserta Pendidikan Dokter Gigi Spesialis Ilmu Penyakit Mulut Fakultas Kedokteran Gigi Universitas Airlangga, Jl. Mayjen Prof. Dr. Moestopo No. 47, Surabaya 60132, Indonesia.

\section{PENDAHULUAN}

Kandidiasis oral adalah penyakit pada mukosa rongga mulut yang disebabkan oleh
Candida yang merupakan fungi yang paling sering menginfeksi tubuh manusia. ${ }^{1}$ Fungi adalah suatu mikroorganisme oportunistik patogen terutama 
pada pasien imunokompromis, yang dapat diperberat oleh adanya faktor lokal ataupun proses patologik sistemik. Kandidiasis oral dapat merupakan gambaran adanya penurunan mekanisme pertahanan lokal dan sistemik, antara lain penurunan jumlah sekresi saliva, penurunan imunitas seluler dan humoral, penyakit mukosa lokal atau penggunaan antibiotik spektrum luas dan agen imunosupresif, yang juga merupakan beberapa faktor predisposisi yang memicu timbulnya penyakit ini. ${ }^{2}$ Kadir dkk melaporkan pada penelitiannya terhadap rongga mulut 300 anak-anak sehat, dapat diisolasi enam spesies Candida (karier kandida) yaitu 84,8\% C.albicans, sisanya C. parapsilosis, C.krusei, C.kefyr, C.famata, and C.tropicalis yang berkaitan dengan minuman mereka. Dapat diidentifikasi prevalensi karier Candida, 18,5\% pada anak-anak yang mengkonsumsi air susu ibu (ASI), susu botol atau cairan manis lainnya. Sedangkan anak yang mengkonsumsi ASI saja, tidak ditemukan karier Candida. $^{3}$

Sebagian besar kandidiasis oral disebabkan oleh C.albicans (CA), meskipun dapat juga disebabkan oleh oleh non-candida albicans Candida (NCAC) yang mempunyai jenis manifestasi klinis yang sama, yaitu erythyema candidiasis, pseudomembranous candidiasis, median rhomboid glossitis, angular cheilitis dan candidal leukoplakia. Perbedaaan hanya pada sifat invasif masing-masing spesies dan respon terhadap obat-obat antifungi. $^{2}$

Diagnosis kandidiasis oral ditegakkan dengan melakukan pemeriksaan mikologi, dan pengambilan spesimen dengan cara swab pada permukaan lesi yang diduga telah terinfeksi Candida. Pemeriksaan kandidiasis dapat dilakukan secara direct atau indirect. Pemeriksaan direct adalah pemeriksaan yang paling mudah dan murah untuk melihat keberadaan Candida.
Pelaksanaannya dapat menggunakan $\mathrm{KOH}$, pengecatan toluen blue dan Gram. Pada kasus ini pemeriksaan direct menggunakan pengecatan Gram. Candida seperti halnya fungi lainnya termasuk gram positif yang biasanya dapat dilihat menggunakan pengecatan Gram. Namun demikian, pemeriksaan direct ini kurang sensitif karena seringkali didapatkan hasil false negative. Untuk itu, pemeriksaan indirect/kultur diperlukan untuk memastikan ada tidaknya Candida serta mengidentifikasi spesiesnya. Hingga saat ini pemeriksaan polymerase chain reactions (PCR) untuk mendeteksi DNA Candida juga masih dianggap kurang sensitif jika dibandingkan dengan menggunakan pemeriksaan kultur., ${ }^{4,5}$

Candida tropicalis (CT) termasuk dalam phylum ascomycota, orde saccharomycetales dan dalam kelas hemiascomycetes. ${ }^{5}$ Morfologi makroskopis CT pada kultur sabouraud's dextrose agar (SDA) modifikasi dengan suhu $25-37{ }^{\circ} \mathrm{C}$ terlihat koloni berwarna putih hingga krem. Koloni bertekstur halus, basah dan mengkilat ataupun tampak bertumpuk, kasar dan waxy. Sekeliling perifer koloni dapat terlihat terbenam di dalam media agar. $^{6}$ Identifikasi Candida juga dapat dengan melakukan kultur pada chromogenic agar medium (CHROMagar Candida $^{\mathrm{TM}}$ ) dan spesies ini akan nampak sebagai koloni berwarna biru hingga biru keabu-abuan. ${ }^{2,47}$ Pada kasus ini identifikasi Candida dilakukan dengan kultur pada media SDA, kemudian diperiksa dengan menggunakan API 20C AUX kit yang terdiri dari sebuah 20-cupule plastic strip yang mengandung substrat dehydrated carbohydrate. Strip ini diinokulasi dengan 1:70 dilusi suspensi anorganik yang disesuaikan menggunakan standar McFarland 2.0, kemudian diinkubasi pada suhu $30{ }^{\circ} \mathrm{C}$ selama 48-72 jam (sesuai aturan pabrik). Setelah diinkubasi pada masing-masing cupule pada setiap strip akan dapat dilihat secara visual 
adanya kekeruhan yang menunjukkan adanya asimilasi karbohidrat. Hasil dan identifikasi diperoleh dengan menggunakan program APILAB plus V 3.3.2. ${ }^{8}$

Gambaran terpenting dalam identifikasi CT adalah ditemukannya koloni yeast-form dan strukur mikroskopik pada suhu $15^{\circ} \mathrm{C}$ dan $37^{\circ} \mathrm{C}$, adanya bentukan blastoconidia dan pseudohifa dalam satu waktu, tidak adanya kapsul dan germ tube serta terdapatnya surface film dengan gelembung-gelembung pada media sabouraud's dextrose broth (SDB). ${ }^{6}$

Monisilia candida, Oidium tropicalis, Mycotorula dimorpha, $M$. trimorpha adalah nama lain CT yang merupakan salah satu spesies NCAC yang mempunyai virulensi paling tinggi di golongan spesiesnya, karena mempunyai kemampuan perlekatan paling tinggi pada sel-sel epitel secara in vitro dan mensekresi proteinase dalam level sedang. ${ }^{2}$ Selain itu CT juga merupakan spesies Candida nomor dua yang paling sering dijumpai koloninya pada manusia dan dapat menyebabkan kandidiasis yang serius pada pasien imunokompromis. ${ }^{6,13}$ Spesies ini juga menempati peringkat ketiga dan keempat paling sering ditemukan dalam kultur darah penderita leukemia, neutropenia yang lama, dan pasien ICU dalam waktu lama terjadinya kandidemia karena CT. ${ }^{4}$ Penelitian yang melaporkan $\mathrm{CT}$ sebagai penyebab kandidiasis oral dapat diidentifikasi pada $16 \%$ pasien rawat inap di Mesir, yang dipicu karena penggunaan obat-obat anti fungi khusus ataupun akibat penggunaan antibiotika sistemik. Walaupun angka insidensi infeksi dalam rongga mulut kecil tetapi spesies ini mempunyai potensi virulensi yang akhir-akhir ini dilaporkan menjadi penyebab utama candidemia oleh karena NCAC. ${ }^{9}$

Tujuan penulisan artikel adalah melaporkan terjadinya kandidiasis oral oleh karena CT pada anak dengan gangguan sistemik. Diagnosis ditegakkan berdasarkan hasil anamnesis, manifestasi klinis dan pemeriksaan laboratorium.

\section{KASUS}

Pada tanggal 23 Juli 2009, seorang anak lakilaki berusia 4 tahun (Gambar 1) datang ke Bagian Penyakit Mulut RSAL Dr Ramelan Surabaya dengan keluhan gusi berdarah dan nyeri, lidah terasa nyeri sehingga pasien sulit makan dan minum. Empat hari sebelumnya pasien mengalami malaise dan demam $40{ }^{\circ} \mathrm{C}$ sehingga dibawa orang tuanya berobat ke RS PHC Surabaya. Dokter memberinya obat amoksisilin dengan sirup asam clavulanic, parasetamol dan puyer, serta dirujuk untuk melakukan pemeriksaan darah lengkap. Pada tanggal 20 Juli 2009 terasa gejala kurang nyaman di rongga mulutnya dan pasien mulai sulit menelan dan minum susu. Tiga hari kemudian pasien datang ke RSAL karena kondisi rongga mulutnya justru semakin memburuk, dan suhu badan $37,5^{\circ} \mathrm{C}$.

Pemeriksaan intraoral mendapati pseudomembran warna putih pada lidah dan palatum, dapat dikerok, meninggalkan bekas yang eritem, dan sangat nyeri. Gingiva rahang atas dan bawah udem, eritem, mudah berdarah, serta terdapat fistula pada gingiva rahang bawah. Seluruh mukosa mulut menunjukkan gambaran mukositis yang menyeluruh dengan warna eritem dan nampak sangat sensitif. Secara umum kebersihan mulut pasien terlihat buruk, dengan seluruh gigi didiagnosis sisa akar (Gambar 2).

Pada pemeriksaan ekstraoral, palpasi pada kelenjar limfe submandibularis kanan teraba, kenyal, sakit dapat digerakkan, dan kelenjar kiri teraba lebih besar, keras dan sakit. Kondisi umum terlihat pasien pucat, lesu, mata sayu, mulut sedikit terbuka dan saliva selalu menetes keluar.

Pasien masih minum susu dengan botol dan pada tahun sebelumnya pasien menderita 
tuberkulosis dan telah diobati teratur selama 1 tahun sesuai instruksi dokter sampai dinyatakan sembuh.

\section{Tata laksana kasus}

\section{Kunjungan pertama (23 Juli 2009)}

Berdasarkan anamnesis dan pemeriksaan klinis, kasus ini didiagnosis klinis sebagai pseudomembranous candidiasis, dengan difteri sebagai diagnosis banding. Pasien dirujuk untuk pemeriksaan mikologi. Hasil pemeriksaan darah lengkap yang dilakukan pada tanggal 20 Juli 2009 didapatkan $\mathrm{Hb} 11,5$ (N: 12,0-17,0), eritrosit 4,82 $(\mathrm{N}: 4,50-6,50)$, hematrokrit 36,6 (N: 37,0-47,0), MCV 75,9 (N: 79,0-97,0), MCH 23,9 (N: 27,031,0 ), dan MCHC 31,4 (N: 32,0-36,0) yang menunjukkan pasien mengalami anemia.

Pasien diinstruksikan untuk membersihkan rongga mulutnya terutama pada dorsum lidahnya. Diberikan obat Nystatin suspensi oral $5 \mathrm{ml}$ (500.000 unit), 3 x sehari, dikulum dalam rongga mulut kemudian diratakan pada seluruh mukosa lalu ditelan. Kepada pasien juga diberikan sirup multivitamin $60 \mathrm{ml}$ (Vitamin A, B1, B2, B6, B12, C, dan D) 1 sendok takar sehari, dan parasetamol $5 \mathrm{ml}$ jika demam. Peningkatan asupan nutrisi pasien disarankan dengan mengkonsumsi makanan tinggi kalori tinggi protein (TKTP) cair dan mengoptimalkan pemberian susu. Pasien disarankan kontrol tanggal 30 Juli 2009.

\section{Kunjungan kedua (24 Juli 2009)}

Keesokan harinya orang tua pasien datang menyerahkan hasil pemeriksaan mikologi direct dengan hasilnya negatif (-). Dari anamnesis diketahui obat digunakan sesuai aturan, tetapi kondisi pasien belum banyak berubah, terlihat lesu dan lemah, dan suhu badan $37^{\circ} \mathrm{C}$.

Pada pemeriksaan intraoral, pseudomembran pada lidah telah berkurang, tetapi terlihat adanya erosi pada dorsum lidah, kemerahan dan sakit (Gambar 3).

Pasien diinstruksikan untuk terus menjaga kebersihan mulut, diet TKTP cair dan istirahat yang cukup, serta obat-obatan dilanjutkan. Pasien mengeluh perih dan tidak enak pada Nystatin suspensi oral sehingga ditambahkan pemberian $\mathrm{H}_{2} \mathrm{O}_{2}$ 1,5\% untuk dikumurkan atau dioleskan perlahan menggunakan kasa steril pada seluruh mukosa mulutnya.

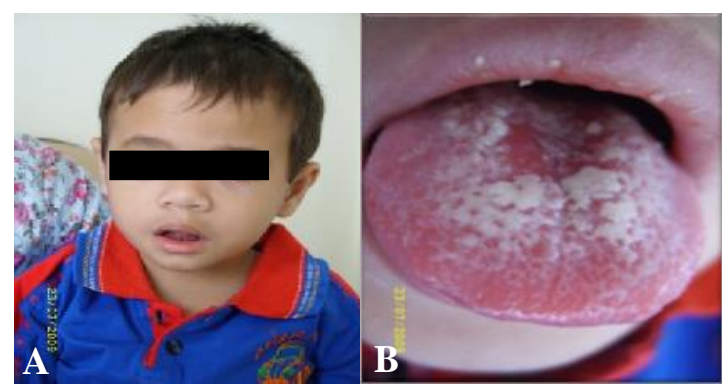

Gambar 1. Pada kunjungan pertama. A tampak ekstra oral pasien pucat, lesu, mulut sedikit terbuka. B. Pada lidah dan palatum terdapat pseudomembran warna putih.
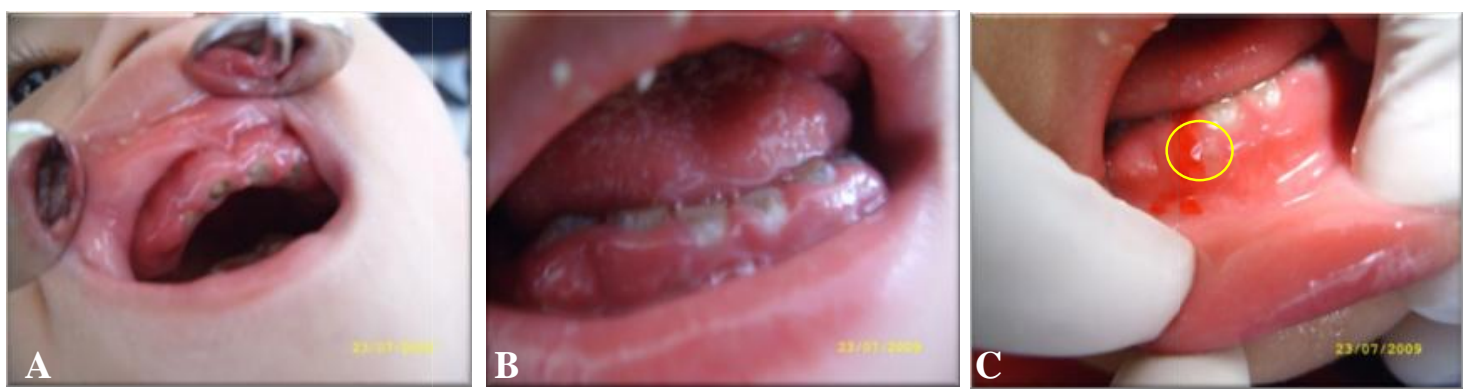

Gambar 2. Intra oral kunjungan pertama memperlihatkan A \& B. gingiva yang udem, eritematus, dan C. mudah berdarah serta fistula pada gingiva rahang bawah. 


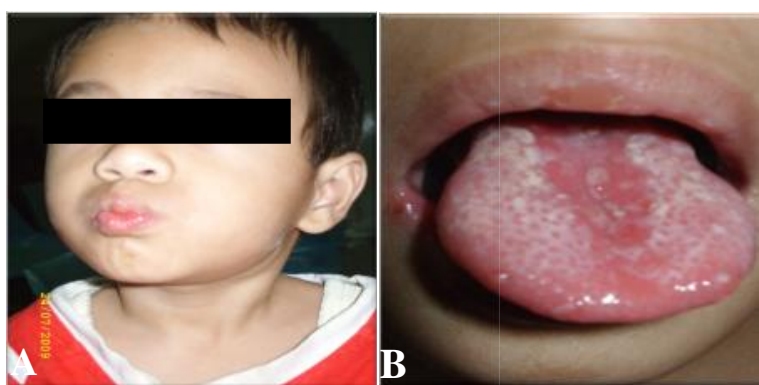

Gambar 3. Gambaran pada kunjungan kedua.

A. Ekstra oral, pasien masih terlihat lesu dan lemah. B. Pseudomembran telah berkurang, permukaan dorsum lidah yang erosif, dan eritematus.

\section{Kunjungan ketiga (30 Juli 2009)}

Pada kontrol kedua, hari ketujuh, pasien telah merasa lebih nyaman dan tidak ada keluhan pada rongga mulutnya, suhu badan telah normal dan kondisi umum telah pulih. Obat-obatan yang diberikan digunakan sesuai aturan.

Pada pemeriksaan intraoral, lidah berwarna normal, dorsum lidah terlihat depapilasi tetapi tidak sakit. Gingiva berwarna normal, tidak mudah berdarah dan fistula pada gingiva rahang bawah masih ada. Kebersihan mulut telah lebih baik, dan gambaran mukositis tidak terlihat lagi (Gambar 4).

Hasil tes mikologi indirect, positif (+) Candida tropicalis. Pasien diinstruksikan untuk melanjutkan pengobatan dan disarankan kontrol tanggal 6 Agustus 2009.

\section{Kunjungan keempat (6 Agustus 2009)}

Pasien telah merasa sangat nyaman sehingga dapat makan dan minum dengan baik, dan obatobatan digunakan sesuai petunjuk.

Pada intraoral terlihat sedikit debris pada dorsum lidah, warna lidah normal, papila normal. Secara umum keseluruhan rongga mulut normal. Pemeriksaan ekstraoral tidak nampak adanya kelainan, kondisi umum pasien baik (Gambar 5). Pasien dinyatakan sembuh, pemakaian Nystatin dihentikan, pembersihan dengan menggunakan $\mathrm{H} 2 \mathrm{O} 2$ 1,5\% dilanjutkan dan kebersihan mulut tetap ditekankan mengingat pasien masih minum susu formula menggunakan botol. Selanjutnya pasien dirujuk ke poli pedodontik, gizi, dan anak.
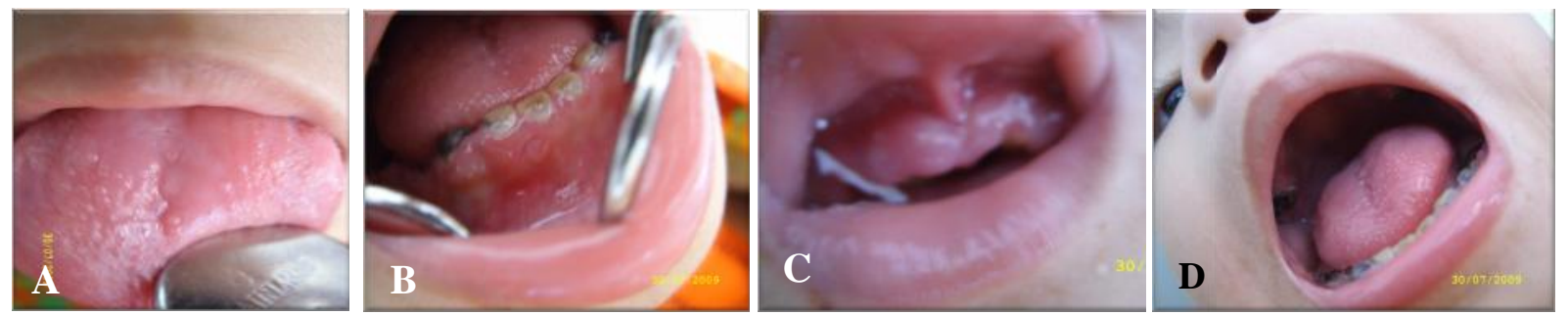

Gambar 4. Tampak pada kunjungan ketiga. A. lidah berwarna normal, depapilasi, B dan C. Gingiva berwarna normal, udem telah banyak berkurang, D. Secara umum gambaran mukositis menyeluruh yang terlihat sebelumnya tidak terlihat lagi dan kebersihan mulut membaik.
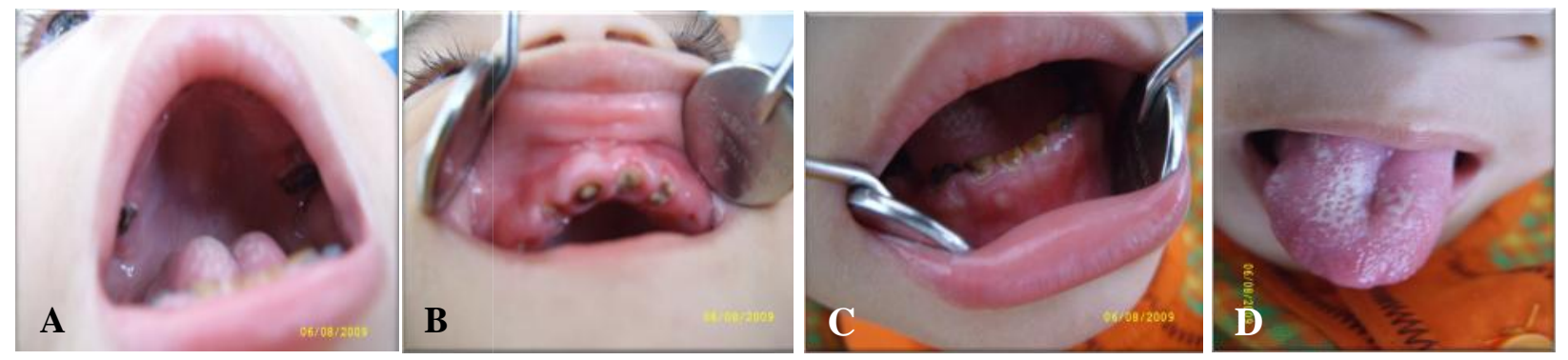

Gambar 5. Pada kunjungan keempat secara umum A, B, dan $\mathbf{C}$ seluruh mukosa rongga mulut dan gingiva normal. C. Terlihat sedikit debris pada permukaan dorsum lidah, warna lidah dan papila normal. 


\section{PEMBAHASAN}

Candida merupakan penyebab terjadinya kandidiasis baik sistemik maupun superfisial, dan biasanya spesies yang paling sering ditemukan adalah CA. Akan tetapi, akhir-akhir ini kejadian infeksi NCAC terus meningkat., ${ }^{2,410}$ Kebersihan mulut yang buruk, malnutrisi, usia sangat muda, gangguan sistemik dan konsumsi susu formula menggunakan botol merupakan beberapa faktor predisposisi terjadinya kandidiasis oral. ${ }^{3,11,12}$

Pasien adalah seorang anak dengan usia yang sangat muda, kebersihan mulut yang buruk, seluruh gigi adalah sisa akar, seluruh mukosa mulut berwarna merah menyerupai mukositis. Kondisi tubuhnya lebih kecil dari anak sebayanya (BB $\pm 15 \mathrm{~kg}$ ), sedangkan BB ideal usia 4 tahun adalah $16 \mathrm{~kg}$ ((usia x 2)+8). Anak sulit makan, hanya makan kue dan minum susu formula saja. Kondisi umum yang lemah, secara klinis menggambarkan terjadinya malnutrisi. ${ }^{13}$

Hasil pemeriksaan darah lengkap adalah sel darah merah hipokromik mikrositik yang mencerminkan penderita mengalami anemia defisiensi zat besi akibat malnutrisi. Meskipun demikian diperlukan pemeriksaan zat besi serum, kapasitas serum mengikat zat besi, saturasi transferin dan kadar feritin serum untuk memastikan anemia akibat penyakit kronis atau talasemia minor. Pada kondisi yang tidak terlalu parah anemia defisiensi besi menunjukkan gambaran sel darah merah normokromiknormositik atau hipokromik normositik. ${ }^{13}$

Suhu badan pasien ketika datang telah turun menjadi $37,5^{\circ} \mathrm{C}$ karena telah mendapatkan terapi antibiotik spektrum luas (amoksisilin dengan asam klavulanat), dan parasetamol. Febris yang terjadi sebelumnya diperkirakan akibat infeksi karena menurut orang tua, tidak disertai tanda-tanda lain seperti influensa, atau keluhan lain. Dokter sebelumnya hanya memberi keterangan bahwa febris terjadi karena dehidrasi sehingga selain obat, pasien disarankan untuk banyak minum. Keadaan ini menyebabkan kondisi umum pasien semakin lemah dan mencetuskan infeksi Candida. Antibiotik tersebut dapat mengubah keseimbangan mikroorganisme komensal rongga mulut dan menghambat pertumbuhan bakteri komensal yang bersifat antagonis terhadap Candida, sehingga terjadi peningkatan populasi Candida. ${ }^{1,14}$

Pada kunjungan awal, karena gambaran klinis nampak sebagai kandidiasis pseudomembran maka diberikan obat antifungi Nystatin suspensi oral, dan sirup parasetamol jika ada peningkatan suhu badan, serta multivitamin dan instruksi diet TKTP cair sebagai terapi suportif. Pasien juga diinstruksikan untuk membersihkan rongga mulutnya, dan dirujuk untuk melakukan pemeriksaan mikologi.

Multivitamin yang diberikan mengandung vitamin A $3000 \mathrm{IU}, \mathrm{D} 400 \mathrm{IU}, \mathrm{B} 13 \mathrm{mg}, \mathrm{B} 2$ 1,5 $\mathrm{mg}$, B6 0,5 mg, B12 $5 \mathrm{mcg}$, dan C $30 \mathrm{mg}$ dengan dosis satu sendok takar sekali sehari. Multivitamin ini diharapkan dapat membantu meningkatkan kondisi umum pasien yang lemah. Vitamin A diperlukan untuk diferensiasi dan pertumbuhan jaringan epitel dan meningkatkan fungsi sistem imun. Vitamin B kompleks memegang peranan sebagai koenzim pada banyak reaksi biokimia dan metabolisme karbohidrat yang memperlancar metabolisme tubuh manusia, dan meningkatkan stamina tubuh secara umum. Vitamin $\mathrm{C}$ berperan penting sebagai kofaktor pada hidroksilasi residu prolin untuk sintesis kolagen, memelihara jaringan konektif serta membantu sintesis jaringan konektif pada saat terjadi penyembuhan. ${ }^{15}$ Pemberian diet TKTP cair untuk menggantikan nutrisi yang seharusnya didapatkan pasien, sehingga dapat menambah energi untuk proses penyembuhan. Rehidrasi diperlukan untuk mengembalikan cairan tubuh yang keluar akibat demam. 
Hasil pemeriksaan mikologi direct negatif (-), mungkin karena kurang sensitifnya pemeriksaan ini sehingga perlu dilakukan pemeriksaan indirect. Karena kandidiasis oral merupakan infeksi fungi superfisial maka sebaiknya pengobatan yang diberikan adalah terapi lokal. ${ }^{2}$ Terapi antifungi yang diberikan pada kasus ini adalah Nystatin, walaupun dari pemeriksaan direct tidak ditemukan Candida. Terapi antifungi dilanjutkan karena gambaran klinis menunjukkan infeksi Candida, sambil menunggu hasil pemeriksaan indirect.

Nystatin adalah suatu macrolide polyene yang toksisitasnya rendah jika digunakan sebagai obat topikal walaupun mempunyai rasa yang kurang enak, efektif terhadap sebagian besar spesies Candida dan paling sering digunakan untuk menekan infeksi Candida lokal. Antifungi polyene berikatan dengan ergosterol pada membran sel fungi, sehingga terjadi gangguan pada stuktur membran sel yang menyebabkan kebocoran kandungan intrasel yang berakhir dengan kematian sel. Dosis pemberian yang disarankan untuk anak-anak adalah 4-6 ml. ${ }^{16}$

Untuk mengoptimalkan kebersihan mulut, karena pasien mengeluhkan rasa yang kurang enak pada penggunaan Nystatin suspensi oral maka ditambahkan $\mathrm{H}_{2} \mathrm{O}_{2} \quad 1,5 \%$ yang penggunaannya bergantian dengan Nystatin suspensi oral dengan tenggang waktu. Hidrogen peroksida merupakan biocide yang telah digunakan secara luas sebagai larutan desinfektan, sterilisasi dan antiseptik, dan berupa larutan bening, menunjukkan spektrum yang luas melawan bakteri, virus, jamur, dan spora bakteri, dan pada umumya lebih besar aktivitasnya terhadap organisme gram positif. Pada konsentrasi yang rendah akan dapat meningkatkan toleransinya dengan keberadaan katalase atau peroksida dalam organisme. Peroksida ini juga bersifat sebagai oksidan dengan memproduksi radikal bebas $(\mathrm{OH})$ yang dapat merusak komponen sel esensial termasuk lemak, protein dan DNA. ${ }^{17}$ Bahan ini juga disebut oxygenating compound karena menghasilkan oksigen, sehingga penggunaannya sebagai obat kumur dapat membantu mengeliminasi bakteribakteri anaerob, membantu debridemen jaringan yang luka. Konsentrasi yang disarankan sebagai obat kumur adalah adalah 1,5-3\%. ${ }^{18}$

Pada kunjungan ketiga kondisi pasien semakin membaik dan hasil pemeriksaan mikologi indirect/kultur menunjukkan positif CT. Keberadaan CT tidak seperti CA yang merupakan komensal rongga mulut tetapi biasanya berkaitan dengan adanya perkembangan suatu infeksi fungi dalam tubuh host dan CT lebih tidak virulen jika dibandingkan dengan CA karena NCAC tidak memiliki atau hanya memiliki sebagian faktor virulensi yang dimiliki oleh CA. ${ }^{2,9,19,20}$

Timbulnya kandidiasis oral tidak terlepas dari faktor-faktor predisposisi yang mencetuskan kelainan tersebut dan kebersihan mulut yang kurang terjaga. ${ }^{14}$ Oleh karena itu penatalaksanaan kasus ini adalah mengeliminasi faktor-faktor predisposisi, yaitu dengan meningkatkan asupan nutrisi dengan pemberian diet TKTP cair mengingat jenis anemianya kemungkinan besar akibat malnutrisi dengan kondisi fisik yang lemah, rehidrasi, optimalisasi kebersihan mulut serta pemberian obat anti fungi. Pemberian Nystatin suspensi oral cukup efektif untuk mengeliminasi infeksi CT. Dengan demikian jika pada pasien secara klinis dan mikologis menunjukkan suatu kandidiasis akibat CT, dipertimbangkan memilih penggunaan anti fungi Nystatin suspensi oral sebagai salah satu pilihan obat.

\section{SIMPULAN}

Disimpulkan bahwa kandidiasis oral ternyata juga dapat disebabkan oleh CT, kandidiasis oral yang disebabkan oleh CA maupun CT dapat 
memberikan gejala yang secara klinis hampir sama, walaupun angka insidensi kandidiasis oral akibat CT ini masih relatif kecil tetapi spesies ini dilaporkan mempunyai potensi virulensi menjadi penyebab kandidemia karena NCAC pada pasien imunokompromis, dan respon terhadap antifungi fluconazole pada penelitian in vitro menunjukkan respon yang kurang menggembirakan.

\section{SARAN}

Penanganan pasien ini memerlukan perawatan yang melibatkan berbagai disiplin agar dokter gigi dapat melakukan penanganan yang optimal pada pasien dan menghindari timbulnya akibat yang tidak diinginkan.

\section{DAFTAR PUSTAKA}

1. Greenberg M, Glick M. Burkets oral medicine diagnosis \& treatment. $10^{\text {th }}$ Ed. New Jersey: BC Decker Inc; 2003. p. 547-50; 563-5.

2. Meurman J, Siikalal E, Richardson M, Rautemaa. Non-Candida albicans Candida yeasts of the oral cavity; communicating current research and educational topics and trends. In: Méndez-Vilas A, editor. Applied microbiology. 2007. p. 719-31.

3. Kadir T, Uygun B, Akyüz. Prevalence of Candida species in Turkish children: relationship betweendietary intake and carriage. Arch Oral Biol 2005; 50: 33-7.

4. Dismukes W, Pappas P, Sobel J. Clinical mycology. Oxford: Oxford University Press Inc; 2003. p. 63-70.

5. Webster W. Introduction to fungi. Cambridge: Cambridge University;2007.p.440-5.

6. Fisher F, Cook N. Fundamental of diagnostic mycology. St.Louis: Saunders; 1998.p.25-212.

7. Crocco E. Identification of Candida species and antifungal susceptibility in vitro: a study on 100 patients with superficial candidiasis; An Bras Dermatol 2004; 79(6): 689-97.

8. Hatta J, Hall L, Fothergill A. Multicenter evaluation of new VITEK 2 advanced colorimetric test identification card. J Clin Microbiol 2007; 45(4): 1087-92.
9. Shaheen T. Species identification of Candida isolates obtained from oral lesions of hospitalized and non hospitalized patients with oral candidiasis. Egyptian Dermatol Online J 2006; 2(1) 1-13.

10. Dassanayake RS, Samaranayake YH. DNA fingerprinting elicited evolutionary trend of Candida tropicalis isolates from diverse geographic locales. Indian J Med Microbiol 2006; 24 (3): 186-94.

11. Samaranayake L. Essential microbiology for dentistry. London: Churrchill Livington; 2006. p.177-84.

12. Regezi J, Sciubba J, Jordan R. Oral pathology. St Louis: Sunders; 2008. p.100-4; 134-5.

13. Kumar V,Abbas A,Fausto N. Basic pathology. $8^{\text {th }}$ Ed. Philadelphia: Saunders; 2008. p.43540.

14. Bagg J, MacFarlane TW, Poxton IR, Smith AJ, Bagg S. Essentials of microbiology for dental students. $2^{\text {nd }}$ Ed. Oxford: Oxford University Press; 2006. p. 274-80.

15. Singh S. Pharmacology for dentistry. New Delhi: New Age International (P) Ltd; 2007. P. 383-90.

16. Katzung B. Basic and clinical pharmacology. $10^{\text {th }}$ Ed. San Fransisco: Lange; 2006. p. 345-8.

17. McDonnell G, Russell D. Antiseptics and disinfectants: activity, action, and resistance. Clin Microbiol Rev 1999: 167-79.

18. Yagiela J, Dowd F, Neidle. Pharmacology and therapeutics for dentistry. St.Louis: Westline Industrial Drive; 2004. p.749-50.

19. Barchiesi F, Maracci M, Baldassarri I. Tolerance to amphotericin $\mathrm{B}$ in clinical isolates of Candida tropicalis; Diag Microbiol Infect Dis 2004; 50: 179-85.

20. Haynes K. Virulence in Candida species. Trends Microbiol 2001; 9 (12): 591-6.

21. Barchiesi F, Calabrese D, Sanglard D. Experimental induction of fluconazole resistance in Candida tropicalis ATCC 750. Antimicrobial Agent and Chemotherapy 2000; 44(6): 778-84.

22. Law D, Moore CB, Joseph LA, Keaney MGL, Denning DW. High incidence of antifungal drug resistance in Candida tropicalis. Int $\mathbf{J}$ Antimicrobial Agents 1996; 7: 241-5. 

